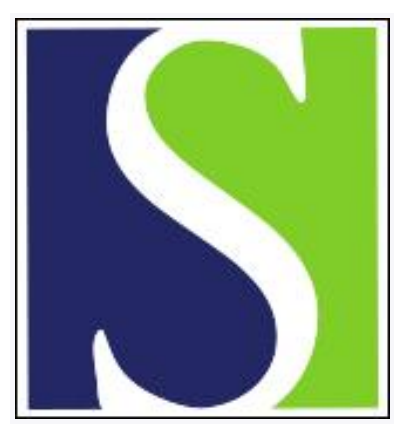

Scand J Work Environ Health 1994;20(3):189-199

https://doi.org/10.5271/sjweh.1409

Issue date: 01 Jun 1994

Impaired nerve conduction in the carpal tunnel of platers and truck assemblers exposed to hand-arm vibration.

by Nilsson T, Hagberg M, Burstrom L, Kihlberg S

Affiliation: Department of Occupational Medicine, Sundsvall Hospital, Sweden.

This article in PubMed: www.ncbi.nlm.nih.gov/pubmed/7973491

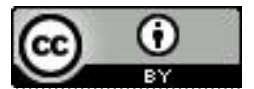




\title{
Impaired nerve conduction in the carpal tunnel of platers and truck assemblers exposed to hand-arm vibration
}

\author{
by Tohr Nilsson, MD, ${ }^{1}$ Mats Hagberg, MD, ${ }^{2}$ Lage Burström, $\mathrm{PhD},{ }^{3}$ Steve Kihlberg, $\mathrm{MSc}^{2}$
}

\begin{abstract}
NILSSON T, HAGBERG M, BURSTRÖM L, KIHLBERG S. Impaired nerve conduction in the carpal tunnel of platers and truck assemblers exposed to hand-arm vibration. Scand $J$ Work Environ Health 1994;20:189-99.

OвJectives - The goal of this study was to assess the relative risks of sustaining impaired nerve conduction in the hands among vibration-exposed persons as opposed to nonvibration-exposed referents.

Methods - In a cross-sectional study design platers and truck assembly workers were contrasted to office workers. The 4-h frequency-weighted vibration was $4.6 \mathrm{~m} \cdot \mathrm{s}^{-2}$ and $1.0 \mathrm{~m} \cdot \mathrm{s}^{-2}$ for the platers and assemblers, respectively. The ergonomic factors were measured as forced grip time. The conduction velocity, distal latency time, and amplitude of the median nerve were measured for both hands.

Results - The sensory nerve conduction velocity was slower in the right hand than in the left. An increased risk of prolonged latency time was found for the platers and assemblers when contrasted to the office workers. The relative risks (rate ratios) of impaired nerve conduction for the carpal tunnel segment varied between 1.4 and 2.0 for the distal latency and between 0.9 and 1.7 for the nerve conduction velocity. The rate ratios were generally higher for the left-hand side than for the right-hand side. The risks were not proportional to either the weighted or unweighted vibration exposure.

Conclusions - The contributions from vibration and ergonomic factors to impaired nerve conduction velocity were inseparable in this study. Ergonomic factors such as forceful gripping and extreme positions, apart from vibration exposure, may be strong determinants of impaired nerve conduction in the carpal tunnel area.
\end{abstract}

KEY TERMS - carpal tunnel syndrome, cross-sectional study, electrophysiology, epidemiology, neuropathy, neurophysiology, risk.

Manual work involving vibrating power tools is considered to be associated with adverse health effects in peripheral microcirculation, the peripheral nervous system, and the musculoskeletal system (1). These effects have been summarized as the hand-arm vibration syndrome, irrespective of the fact that lesions to the different structures can develop either concordantly or independently (2).

The vascular disorder, cold-induced vasospasm or "vibration white fingers," has so far been the most thoroughly investigated of the hand-arm vibration symptoms. Recently, more interest has been focused on the neural impact of vibration. Neural symptoms and signs (eg, numbness, paresthesia, tingling, pain, reduced sensitivity, and manual dexterity) indicate a deranged neural function at the level of the receptors or the axons. The results from measurements of

1 Department of Occupational Medicine, Sundsvall Hospital, Sundsvall, Sweden.

2 National Institute of Occupational Health, Division of Work and Environmental Physiology, Solna, Sweden.

3 National Institute of Occupational Health, Division of Technical Industrial Hygiene, Umeå, Sweden.

Reprint requests to: Dr T Nilsson, Department of Occupational Medicine Sundsvall Hospital, S-851 86 Sundsvall, Sweden. temperature and vibrotactile perception thresholds and two-point discrimination tests are interpreted as evidence of the sensory neural impact of vibration at the level of the receptors (3-5). Measurements supporting the view of a neurological vibration effect on the axon are found in nerve conduction studies (6).

The aim of the present investigation was to assess the relative risks of vibration-exposed persons contracting impaired nerve conduction as opposed to nonvibration-exposed referents.

\section{Subjects and methods}

\section{Study groups}

The investigation was a cross-sectional study of a cohort $(\mathrm{N}=179)$ of platers, truck assemblers, and office workers (figure 1). The criteria for inclusion in the exposure or reference category were as follows: (i) job title (plater, assembler, or office worker), (ii) gender (male), (iii) age (54 years or less), and (iv) work (employed as a plater, assembler, or office worker and working as such). From the total source population of 112 platers listed on the employee rosters, 89 were currently at work and were included in the study population (figure 1). Of the truck assemblers, 70 were randomly admitted from 


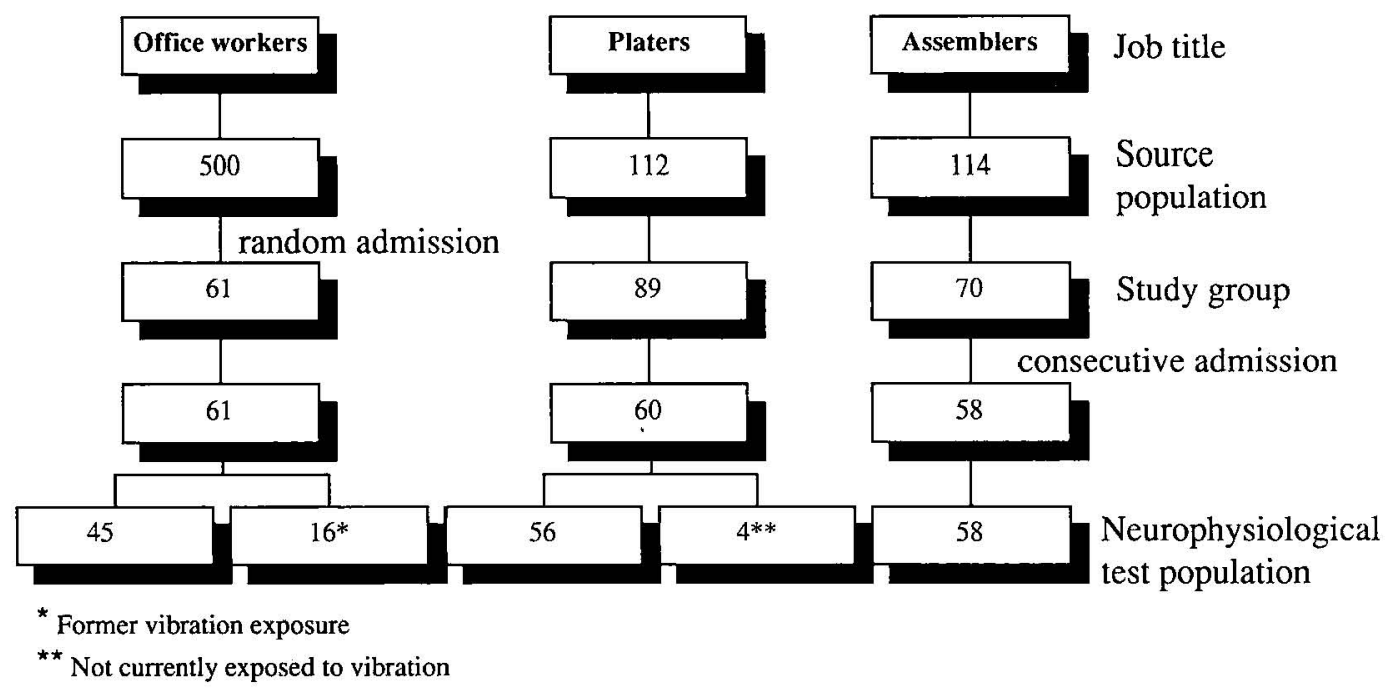

Figure 1. Job titles and the numbers of subjects in the source population and the final study population when the nerve conduction measurements were made.

a source population of 114 . Of the 500 office workers, 61 were randomly admitted. The neurophysiological parameters were measured for all 61 office workers and the first 60 consecutively examined platers and 58 assemblers. An analysis of former and present work revealed that 16 office workers had previously used vibrating tools and four platers currently had no exposure to vibration. The mean age was 32.4 (SD 9.6) years for the plater category, 24.6 (SD 6.4) years for the truck assemblers, and 37.4 (SD 9.8) years for the office workers.

\section{Exposure}

The mean number of years involving exposure to work with hand-held vibrating tools was 12.2 (SD 8.2) years for the platers currently exposed to vibration. For the platers with earlier exposure to handheld vibrating tools the mean exposure time was 10.1 (SD 8.2) years, for the office workers with earlier exposure it was 10.3 (SD 7.8) years, and for the assemblers it was 4.1 (SD 4.6) years.

Ergonomic work load. The platers' work tasks consisted mainly of welding and plating on iron and stainless steel. The work tasks also included finishing the product by grinding. The mean daily time the platers used different repetitive and forced grips was determined from the observation of 12 subjects. The mean percentage of the total worktime involving forced gripping was calculated for the left and right hands separately. The platers used a forced grip 12 min (mean) for the right hand and 9 min (mean) for the left hand per day, which corresponds to $9.8 \%$ of the total daily worktime for the right hand and $9.5 \%$ for the left.
The truck assemblers carried out the mechanical assembly of trucks, using both manual tools and vibrating power tools. The length of time involving different grips was measured for each subject during $18 \mathrm{~min}$ with a sample every second minute. These 18 min represented a balance on the assembly line, which the workers repeated throughout the whole day. The mean percentage of the total worktime involving the left and right hands in a forceful grip was calculated. The truck assemblers used a forced grip $105 \mathrm{~min}$ (mean) for the right hand and $82 \mathrm{~min}$ (mean) for the left hand per day, which corresponds to $22.2 \%$ and $17.3 \%$, respectively, of the daily worktime.

Among the reference group various appointments within office work were represented, such as manager, construction engineer, instructor, and postal clerk. The work content of the reference group varied from engineering construction at a desk to supervision and selling. The main task comprised office work at a desk. Light repetitive manual tasks were present, but forceful grips were not anticipated and thus were not measured.

Vibration exposure. Vibration exposure was assessed under normal work conditions from measurements of the magnitude of the vibration acceleration and the exposure time for each of the tools in use. The tool vibration acceleration was measured at all relevant job stations. The measurements and analyses were carried out in accordance with the ISO 5349 protocol (7), but with different designs for the platers and the assemblers. For the platers measurements were made for 17 grinders, 16 hammers, and 3 die grinders (constituting $13 \%$ of the total number of hand-held vibrating tools in use at the company). For the assemblers vibration was measured for seven nut 
runners, three impact wrenches, two screw drivers, and two wrenches. The accelerometers were glued with a cyanoacrylate cement onto suitable clamps which were mounted on the tools as close as possible to the operator's hand. The data analysis consisted of determining the frequency-weighted and frequency-unweighted levels for the center frequencies of the one-third octave band from 6.3 to $1250 \mathrm{~Hz}$.

The vibration exposure differed between the platers and the assemblers (table 1). The mean levels of the vibration acceleration varied for the different tools between 1.4 and $10.3 \mathrm{~m} \cdot \mathrm{s}^{-2}$ (frequencyweighted) and between 9.8 and $82.4 \mathrm{~m} \cdot \mathrm{s}^{-2}$ (frequency-unweighted).

The daily length of vibration exposure was assessed by means of a subjective rating and by an objective measurement of the time each type of handheld tool was used. The objective measurements were made by observation. Following the company's job analysis for platers (14 853 observations), we studied the tasks demanding the use of hand-held power tools when vibration exposure could be expected. The observation periods lasted $60 \mathrm{~s}$ and the observation time for each operator varied between 120 and 265 min with a mean observation time of 151 (SD $54) \mathrm{min}$. The observer noted the kind of tool the operator was handling, whether the machine was working, and which hand was exposed. Twelve righthanded male platers were observed during active worktime. The data obtained was recalculated according to the data on the frequency of utilization. For the assemblers the frequency study permitted 43 assemblers to be observed every minute for $18 \mathrm{~min}$. The subjective ratings for the length of vibration exposure were collected for the 12 platers observed and for all of the assemblers. The length of vibration ex-

Table 1. Mean frequency-weighted and frequency-unweighted vibration exposure magnitude and mean vibration exposure time measured by the subjective rating of the subjects and by the objective measurement of the tools used by the platers (grinders, hammers and die grinders) and assemblers (nut runners with and without reaction bar, screw drivers and impact wrenches). The resulting total daily acceleration level and corresponding 4-h values are presented.

\begin{tabular}{|c|c|c|c|c|c|c|c|c|c|c|}
\hline \multirow{4}{*}{ Exposed group } & \multirow{3}{*}{\multicolumn{2}{|c|}{$\begin{array}{c}\text { Vibration } \\
\text { magnitude } \\
\left\langle\mathrm{m} \cdot \mathrm{s}^{-2}\right)\end{array}$}} & \multicolumn{8}{|c|}{ Vibration time } \\
\hline & & & \multirow{2}{*}{\multicolumn{2}{|c|}{$\begin{array}{c}\text { Subjective } \\
\text { rating } \\
\left(\min \cdot \mathrm{d}^{-1}\right)\end{array}$}} & \multicolumn{6}{|c|}{$\begin{array}{l}\text { Objective measurement } \\
\left(\min \cdot \mathrm{d}^{-1}\right)\end{array}$} \\
\hline & & & & & \multicolumn{2}{|c|}{ Right hand } & \multicolumn{2}{|c|}{ Left hand } & \multicolumn{2}{|c|}{ Both hands } \\
\hline & Mean & $\mathrm{SD}$ & Mean & SD & Mean & SD & Mean & SD & Mean & SD \\
\hline \multicolumn{11}{|l|}{ Platers } \\
\hline \multicolumn{11}{|l|}{ Tools } \\
\hline \multicolumn{11}{|l|}{ Grinders } \\
\hline $\begin{array}{l}\text { Frequency-weighted } \\
\text { Frequency-unweighted }\end{array}$ & $\begin{array}{r}5.5 \\
82.4\end{array}$ & $\begin{array}{r}1.9 \\
44.1\end{array}$ & $\begin{array}{l}74 \\
\cdots\end{array}$ & $\begin{array}{l}62 \\
\cdots\end{array}$ & $\begin{array}{l}86 \\
\cdots\end{array}$ & $\begin{array}{l}56 \\
\cdots\end{array}$ & $\begin{array}{l}81 \\
\cdots\end{array}$ & $\begin{array}{l}56 \\
\cdots\end{array}$ & $\begin{array}{l}83 \\
\cdots\end{array}$ & 55 \\
\hline \multicolumn{11}{|l|}{ Hammers } \\
\hline $\begin{array}{l}\text { Frequency-weighted } \\
\text { Frequency-unweighted }\end{array}$ & $\begin{array}{l}10.3 \\
76.0\end{array}$ & $\begin{array}{r}2.9 \\
25.2\end{array}$ & $\begin{array}{l}29 \\
\cdots\end{array}$ & $\begin{array}{l}31 \\
\cdots\end{array}$ & $\begin{array}{l}31 \\
\cdots\end{array}$ & 19 & $\begin{array}{l}14 \\
\cdots\end{array}$ & 17 & 22 & $\begin{array}{l}16 \\
\cdots\end{array}$ \\
\hline \multicolumn{11}{|l|}{ Die Grinders } \\
\hline $\begin{array}{l}\text { Frequency-weighted } \\
\text { Frequency-unweighted }\end{array}$ & $\begin{array}{r}1.5 \\
21.5\end{array}$ & $\begin{array}{l}0.3 \\
4.5\end{array}$ & 0 & $\begin{array}{l}\cdots \\
\cdots\end{array}$ & $\begin{array}{l}3 \\
\cdots\end{array}$ & 6 & $\begin{array}{l}1 \\
\cdots\end{array}$ & $\begin{array}{l}2 \\
\cdots\end{array}$ & 2 & $\begin{array}{l}3 \\
\cdots\end{array}$ \\
\hline \multicolumn{11}{|l|}{ Total } \\
\hline $\begin{array}{l}\text { Exposure time } \\
\text { Frequency-weighted }\left(\mathrm{m} \cdot \mathrm{s}^{-2}\right) \\
\text { Frequency-unweighted acceleration }\left(\mathrm{m} \cdot \mathrm{s}^{-2}\right) \\
\text { 4-hour frequency-weighted }\left(\mathrm{m} \cdot \mathrm{s}^{-2}\right) \\
\text { 4-h frequency-unweighted acceleration }\left(\mathrm{m} \cdot \mathrm{s}^{-2}\right)\end{array}$ & $\begin{array}{l}\dot{\cdot} \\
\dot{\cdot} \\
\dot{\cdot}\end{array}$ & $\begin{array}{l}\dot{.} \\
\dot{.} \\
\dot{.}\end{array}$ & $\begin{array}{r}103 \\
7.2 \\
80.7 \\
4.7 \\
52.8\end{array}$ & $\begin{array}{r}2.2 \\
39.2 \\
1.4 \\
25.8\end{array}$ & $\begin{array}{r}120 \\
7.0 \\
79.8 \\
5.0 \\
56.4\end{array}$ & $\begin{array}{r}2.2 \\
39.1 \\
1.5 \\
27: 7\end{array}$ & $\begin{array}{r}96 \\
6.4 \\
81.1 \\
4.0 \\
51.3\end{array}$ & $\begin{array}{r}2.0 \\
21.4 \\
1.3 \\
26.2\end{array}$ & $\begin{array}{r}107 \\
6.8 \\
80.4 \\
4.6 \\
53.7\end{array}$ & \begin{tabular}{r}
\multicolumn{1}{c}{} \\
2.1 \\
40.2 \\
1.4 \\
26.8
\end{tabular} \\
\hline \multicolumn{11}{|l|}{ Assemblers } \\
\hline \multicolumn{11}{|l|}{ Tools } \\
\hline \multicolumn{11}{|l|}{ Nut runner } \\
\hline $\begin{array}{l}\text { Frequency-weighted } \\
\text { Frequency-unweighted }\end{array}$ & $\begin{array}{l}1.4 \\
9.8\end{array}$ & $\begin{array}{l}0.5 \\
2.0\end{array}$ & $\begin{array}{l}20 \\
\cdots\end{array}$ & $\begin{array}{l}\cdots \\
\cdots\end{array}$ & $\begin{array}{l}\cdots \\
\cdots\end{array}$ & $\begin{array}{l}\cdots \\
\cdots\end{array}$ & $\begin{array}{l}\cdots \\
\cdots\end{array}$ & $\begin{array}{l}\cdots \\
\cdots\end{array}$ & $\begin{array}{l}17 \\
\cdots\end{array}$ & $\begin{array}{l}\cdots \\
\cdots\end{array}$ \\
\hline \multicolumn{11}{|l|}{ Wrench } \\
\hline $\begin{array}{l}\text { Frequency-weighted } \\
\text { Frequency-unweighted }\end{array}$ & $\begin{array}{r}1.5 \\
29.9\end{array}$ & $\begin{array}{l}0.5 \\
8.6\end{array}$ & $\begin{array}{l}15 \\
\cdots\end{array}$ & $\begin{array}{l}\cdots \\
\cdots\end{array}$ & $\begin{array}{l}\cdots \\
\cdots\end{array}$ & $\begin{array}{l}\cdots \\
\cdots\end{array}$ & $\begin{array}{l}\cdots \\
\cdots\end{array}$ & $\begin{array}{l}\cdots \\
\cdots\end{array}$ & $\begin{array}{l}9 \\
\cdots\end{array}$ & $\begin{array}{l}\cdots \\
\cdots\end{array}$ \\
\hline \multicolumn{11}{|l|}{ Impact wrench } \\
\hline $\begin{array}{l}\text { Frequency-weighted } \\
\text { Frequency-unweighted }\end{array}$ & $\begin{array}{r}2.9 \\
37.0\end{array}$ & $\begin{array}{l}0.8 \\
7.2\end{array}$ & $\begin{array}{l}2 \\
\cdots\end{array}$ & $\begin{array}{l}\cdots \\
\cdots\end{array}$ & $\begin{array}{l}\cdots \\
\cdots\end{array}$ & $\begin{array}{l}\cdots \\
\cdots\end{array}$ & $\begin{array}{l}\cdots \\
\cdots\end{array}$ & $\begin{array}{l}\cdots \\
\cdots\end{array}$ & $\begin{array}{l}5 \\
\cdots\end{array}$ & $\begin{array}{l}\cdots \\
\cdots\end{array}$ \\
\hline \multicolumn{11}{|l|}{ Screw driver } \\
\hline $\begin{array}{l}\text { Frequency-weighted } \\
\text { Frequency-unweighted }\end{array}$ & $\begin{array}{r}4.0 \\
19.5\end{array}$ & $\begin{array}{l}0.5 \\
3.2\end{array}$ & $\begin{array}{l}3 \\
\cdots\end{array}$ & $\begin{array}{l}\cdots \\
\cdots\end{array}$ & $\cdots$ & $\begin{array}{l}\cdots \\
\cdots\end{array}$ & $\begin{array}{l}\cdots \\
\cdots\end{array}$ & $\begin{array}{l}\cdots \\
\cdots\end{array}$ & $\begin{array}{l}11 \\
\cdots\end{array}$ & $\begin{array}{l}\cdots \\
\cdots\end{array}$ \\
\hline \multicolumn{11}{|l|}{ Total } \\
\hline $\begin{array}{l}\text { Exposure time for vibration } \\
\text { Exposure time for tools where vibration }\end{array}$ & . & . & 40 & $\cdots$ & 40 & $\cdots$ & 41 & $\cdots$ & 40 & $\cdots$ \\
\hline might occur & . & . & . & $\cdot$ & 40 & $\cdots$ & 37 & $\cdots$ & . & . \\
\hline $\begin{array}{l}\text { Frequency-weighted }\left(\mathrm{m} \cdot \mathrm{s}^{-2}\right) \\
\text { Frequency-unweighted acceleration }\left\langle\mathrm{m} \cdot \mathrm{s}^{-2}\right)\end{array}$ & $\dot{.}$ & $\dot{0}$ & $\begin{array}{r}1.9 \\
21.9\end{array}$ & $\begin{array}{l}0.5 \\
5.7\end{array}$ & $\begin{array}{l}\cdots \\
\ldots\end{array}$ & $\cdots$ & $\begin{array}{l}\cdots \\
\cdots\end{array}$ & $\begin{array}{l}\cdots \\
\ldots\end{array}$ & $\begin{array}{r}2.4 \\
22.2\end{array}$ & $\begin{array}{l}0.6 \\
5.0\end{array}$ \\
\hline 4-h frequency-weighted $\left(m \cdot s^{-2}\right)$ & . & . & 0.8 & 1.0 & . & . & . & . & 1.0 & 0.3 \\
\hline 4-h frequency-unweighted acceleration $\left(\mathrm{m} \cdot \mathrm{s}^{-2}\right)$ & . & . & 9.0 & 2.3 & $\cdots$ & . & . & . & 9.3 & 2.1 \\
\hline
\end{tabular}


posure, expressed in minutes for each tool, was rated by the subject for the workday that preceded the day of the observation measurement. All of the subjects in the study population answered a questionnaire on vibration exposure. Information was collected about the onset of vibration exposure, the duration of exposure per day, and the number of years of such exposure. The subjectively and objectively measured exposure duration agreed well (table 1). The corresponding frequency-unweighted accelerations were 53.7 and $10.5 \mathrm{~m} \cdot \mathrm{s}^{-2}$, respectively.

The frequency-weighted energy equivalent acceleration for the period of $4 \mathrm{~h}$ (7) in plating was 4.6 and $1.0 \mathrm{~m} \cdot \mathrm{s}^{-2}$ for the assembly workers when calculated as the mean of the objectively measured exposure time for both hands (table 1).

\section{Measurement of nerve conduction}

The median nerve conduction measurements were performed with a Neuromatic ${ }^{\circledR} 2000 \mathrm{C}$ (two-channel neurograph). The stimulation and recording electrodes were bipolar surface electrodes of salinesoaked felt (diameter $7 \mathrm{~mm}$, spacing $23 \mathrm{~mm}$ ). Nerve distances were measured from the center of the cathode to the active registration electrode. The temperature was carefully controlled and kept above $28^{\circ} \mathrm{C}$.
All of the nerve conduction measurements were measured by the same neurophysiological technician using the same technical setup.

The distal latency time for the median motor nerve was measured after stimulation at the cubital fossa and the wrist with the recording electrode placed on the abductor pollicis brevis muscle. A grounding electrode was set between the stimulation electrode and the recording electrode. The conduction velocity of the median sensory nerve was measured after antidrome percutaneous stimulation. The recordings were fractionated for the carpal tunnel segment and the segment distal to the palm. The stimulation electrode was placed $2 \mathrm{~cm}$ proximal to the distal wrist crease and in the palm. The recording electrode was attached to the ulnar side of the third digit (on the second for the assembler group). The recording electrodes were placed with one of the two felt electrodes proximal and the other distal to the proximal interphalangeal joint. The measurement of the amplitude for the sensory nerve was recorded for the hand segment from the wrist and for the distal segment from the palm to the digit. The case definition of abnormal nerve conduction was based on the $95 \%$ confidence interval $(95 \% \mathrm{CI})$ of the mean (table 2$)$ in the nonvibration-exposed portion of the office worker group with no hand symptoms $(\mathrm{N}=41)$.

Table 2. Mean median motor and sensory nerve conduction velocity, distal latency time, and amplitude measures for the symptomfree, nonvibration-exposed portion of the reference group, case definition and correlation coefficient ( $r$ ) with age, height, and weight. ( $95 \% \mathrm{Cl}=95 \%$ confidence interval)

\begin{tabular}{|c|c|c|c|c|c|c|}
\hline Median nerve & $\begin{array}{c}\text { Mean } \\
\text { amplitude } \\
(\mu \mathrm{V})\end{array}$ & $\begin{array}{c}\text { Mean } \\
\text { velocity } \\
\left(\mathrm{m} \cdot \mathrm{s}^{-1}\right)\end{array}$ & $\begin{array}{c}\text { Case criteria } \\
95 \% \mathrm{Cl} \\
\text { (mean) }\end{array}$ & $\underset{(r)}{\text { Age }}$ & $\begin{array}{l}\text { Height } \\
\text { (r) }\end{array}$ & $\begin{array}{l}\text { Weight } \\
\text { (r) }\end{array}$ \\
\hline \multicolumn{7}{|l|}{ Motor } \\
\hline \multicolumn{7}{|c|}{ Conduction velocity } \\
\hline $\begin{array}{l}\text { Right arm } \\
\text { Left arm }\end{array}$ & $\dot{.}$ & $\begin{array}{l}61.9 \\
61.6\end{array}$ & $\begin{array}{l}<60.3 \\
<59.7\end{array}$ & $\begin{array}{l}-0.19 \\
-0.39\end{array}$ & $\begin{array}{l}-0.21 \\
-0.31^{\star}\end{array}$ & $\begin{array}{l}-0.21 \\
-0.41^{*}\end{array}$ \\
\hline \multicolumn{7}{|c|}{ Distal latency time } \\
\hline $\begin{array}{l}\text { Right arm } \\
\text { Left arm }\end{array}$ & . & $\begin{array}{l}3.60 \\
3.59\end{array}$ & $\begin{array}{l}>3.74 \\
>3.73\end{array}$ & $\begin{array}{l}0.21 \\
0.28\end{array}$ & $\begin{array}{l}0.33^{\star} \\
0.24\end{array}$ & $\begin{array}{l}0.37^{\star} \\
0.05\end{array}$ \\
\hline \multicolumn{7}{|l|}{ Sensory } \\
\hline \multicolumn{7}{|c|}{ Conduction velocity } \\
\hline \multicolumn{7}{|l|}{ Wrist-digit } \\
\hline $\begin{array}{l}\text { Right } \\
\text { Left }\end{array}$ & $\dot{.}$ & $\begin{array}{l}52.3 \\
54.6\end{array}$ & $\begin{array}{l}<50.9 \\
<53.2\end{array}$ & $\begin{array}{l}-0.35 \\
-0.31^{\star}\end{array}$ & $\begin{array}{l}-0.05 \\
-0.27\end{array}$ & $\begin{array}{l}-0.23 \\
-0.21\end{array}$ \\
\hline \multicolumn{7}{|l|}{ Palm-digit } \\
\hline $\begin{array}{l}\text { Right side } \\
\text { Left side }\end{array}$ & $\dot{r}$ & $\begin{array}{l}53.5 \\
58.1\end{array}$ & $\begin{array}{l}<51.4 \\
<55.5\end{array}$ & $\begin{array}{l}-0.21 \\
-0.22\end{array}$ & $\begin{array}{l}0.02 \\
0.09\end{array}$ & $\begin{array}{l}-0.19 \\
-0.09\end{array}$ \\
\hline \multicolumn{7}{|l|}{ Wrist-palm } \\
\hline $\begin{array}{l}\text { Right side } \\
\text { Left side }\end{array}$ & $\dot{\cdot}$ & $\begin{array}{l}52.7 \\
53.0\end{array}$ & $\begin{array}{l}<50.0 \\
<50.1\end{array}$ & $\begin{array}{l}-0.36^{\star} \\
-0.09\end{array}$ & $\begin{array}{l}-0.09 \\
-0.27\end{array}$ & $\begin{array}{l}-0.19 \\
-0.09\end{array}$ \\
\hline \multicolumn{7}{|l|}{ Amplitude } \\
\hline \multicolumn{7}{|l|}{ Wrist-digit } \\
\hline $\begin{array}{l}\text { Right side } \\
\text { Left side }\end{array}$ & $\begin{array}{l}14.2 \\
15.2\end{array}$ & $\dot{.}$ & $\begin{array}{l}<12.6 \\
<13.7\end{array}$ & $\begin{array}{l}-0.44^{\star} \\
-0.29\end{array}$ & $\begin{array}{l}-0.10 \\
-0.22\end{array}$ & $\begin{array}{l}-0.23 \\
-0.04\end{array}$ \\
\hline \multicolumn{7}{|l|}{ Palm-digit } \\
\hline $\begin{array}{l}\text { Right side } \\
\text { Left side }\end{array}$ & $\begin{array}{l}11.3 \\
12.6\end{array}$ & $\dot{.}$ & $\begin{array}{l}<9.8 \\
11.1\end{array}$ & $\begin{array}{l}-0.36^{*} \\
-0.05\end{array}$ & $\begin{array}{l}-0.02 \\
-0.04\end{array}$ & $\begin{array}{l}-0.13 \\
-0.30\end{array}$ \\
\hline
\end{tabular}

* $P<0.05$. 
All of the subjects in the study population were examined and interviewed by a physician (TN). This examination was performed to identify and check for other diseases, special attention being paid to polyneuropathy and cervical radiculopathy. No subjects were identified and excluded due to presumed alcoholic neuropathy or abnormal clinical findings. The subjects provided demographic data through a questionnaire. The questions covered, for example, age, work, years at work, exposure, and use of nicotine.

\section{Statistics}

Frequency measures were computed as point prevalence rates given in percentages. The unpaired t-test was used for testing the mean differences between groups and the paired t-test for the difference between the left and right hands. Correlations between the nerve conduction measures and the anthropometric values have been given as the Pearson correlation coefficient. The choice of the outcome measure, as well as the measure of association, is controversial in cross-sectional studies. The prevalence rate is regarded by some authors as not ideal as a measure of morbidity because of the composite nature of the prevalence (8). Odds ratio as the measure of association, as advocated by, for example, Checkoway et al (9), is questioned when there are high prevalences. We used rate ratios (relative risk) as the measure of association between effect and exposure. Odds ratios, when presented for comparison, were obtained by computing age-standardized odds ratios according to Mantel-Haenszel techniques. Confidence intervals for rate ratios were calculated according to the Taylor series. An unconditional multiple logistic regression model (10) was used (Epilog) for analyzing interaction effects. The predictors in the multiple 1ogistic regression model were assessed from the variables thought to be of biological importance and reduced to age, consumption of nicotine, vibration exposure, and presence of plating or assembling. Age and years of vibration exposure were treated as continuous variables, while consumption of nicotine and presence of plating or assembling were treated as dichotomous variables. In the logistic regression model the regression coefficients were used to calculate the odds ratios.

\section{Results}

There were negative correlations between the amplitude and the sensory nerve conduction velocities in relation to age, height, and weight (except for conduction velocity in the distal hand segment and height) (table 2). The distal latency time correlated positively with age, height, and weight.

Minor differences were found between the platers and assemblers (table 3 ). Only the conduction veloc-

Table 3. Mean median motor and sensory nerve conduction velocity, distal latency time, and amplitude measures for the platers, assemblers, and office workers and the $95 \%$ confidence interval $(95 \% \mathrm{Cl})$ for the mean difference between the values for the platers and the assemblers.

\begin{tabular}{|c|c|c|c|c|c|c|c|c|c|c|c|c|}
\hline \multirow{3}{*}{ Median nerve } & \multirow{2}{*}{\multicolumn{2}{|c|}{$\begin{array}{l}\text { Platers } \\
(\mathrm{N}=56)\end{array}$}} & \multirow{2}{*}{\multicolumn{2}{|c|}{$\begin{array}{c}\text { Assemblers } \\
(\mathrm{N}=58)\end{array}$}} & \multirow{2}{*}{\multicolumn{2}{|c|}{$\begin{array}{l}\text { Office workers } \\
\qquad(\mathrm{N}=61)\end{array}$}} & \multicolumn{6}{|c|}{ Difference } \\
\hline & & & & & & & \multicolumn{2}{|c|}{$\begin{array}{c}\text { Platers- } \\
\text { office workers }\end{array}$} & \multicolumn{2}{|c|}{$\begin{array}{c}\text { Platers- } \\
\text { assemblers }\end{array}$} & \multicolumn{2}{|c|}{$\begin{array}{l}\text { Assemblers- } \\
\text { office workers }\end{array}$} \\
\hline & Mean & $95 \% \mathrm{Cl}$ & Mean & $95 \% \mathrm{Cl}$ & Mean & $95 \% \mathrm{Cl}$ & Mean & $95 \% \mathrm{Cl}$ & Mean & $95 \% \mathrm{Cl}$ & Mean & $95 \% \mathrm{Cl}$ \\
\hline \multicolumn{13}{|l|}{ Motor } \\
\hline \multicolumn{13}{|c|}{ Conduction velocity } \\
\hline $\begin{array}{l}\text { Right arm } \\
\text { Left arm }\end{array}$ & $\begin{array}{l}62.1 \\
63.2\end{array}$ & $\begin{array}{l}60.5-63.7 \\
61.4-64.8\end{array}$ & $\begin{array}{l}62.1 \\
61.9\end{array}$ & $\begin{array}{l}60.9-63.3 \\
60.5-63.3\end{array}$ & $\begin{array}{l}62.0 \\
61.2\end{array}$ & $\begin{array}{l}60.6-63.4 \\
59.7-62.5\end{array}$ & $\begin{array}{l}0.10 \\
2.00\end{array}$ & $\begin{array}{r}-2.05-2.17 \\
0.00-4.18\end{array}$ & $\begin{array}{l}0.00 \\
1.30\end{array}$ & $\begin{array}{l}-1.99-2.00 \\
-0.76-3.45\end{array}$ & $\begin{array}{l}0.10 \\
0.70\end{array}$ & $\begin{array}{l}-1.91-1.80 \\
-2.71-1.21\end{array}$ \\
\hline \multicolumn{13}{|c|}{ Distal latency time } \\
\hline $\begin{array}{l}\text { Right arm } \\
\text { Left arm }\end{array}$ & $\begin{array}{l}3.65 \\
3.75\end{array}$ & $\begin{array}{l}3.54-3.76 \\
3.65-3.84\end{array}$ & $\begin{array}{l}3.73 \\
3.66\end{array}$ & $\begin{array}{l}3.62-3.84 \\
3.56-3.77\end{array}$ & $\begin{array}{l}3.59 \\
3.59\end{array}$ & $\begin{array}{l}3.49-3.70 \\
3.50-3.70\end{array}$ & $\begin{array}{l}0.06 \\
0.16\end{array}$ & $\begin{array}{r}-0.09-0.21 \\
0.01-0.29\end{array}$ & $\begin{array}{r}-0.08 \\
0.09\end{array}$ & $\begin{array}{l}-0.23-0.07 \\
-0.06-0.22\end{array}$ & $\begin{array}{l}0.14 \\
0.07\end{array}$ & $\begin{array}{l}-0.29-0.01 \\
-0.21-0.08\end{array}$ \\
\hline \multicolumn{13}{|l|}{ Sensory } \\
\hline \multicolumn{13}{|c|}{ Conduction velocity } \\
\hline \multicolumn{13}{|l|}{ Wrist-digit } \\
\hline $\begin{array}{l}\text { Right side } \\
\text { Left side }\end{array}$ & $\begin{array}{l}51.8 \\
54.4\end{array}$ & $\begin{array}{l}50.5-53.1 \\
53.1-55.8\end{array}$ & $\begin{array}{l}50.5 \\
54.0\end{array}$ & $\begin{array}{l}49.0-52.1 \\
52.6-55.4\end{array}$ & $\begin{array}{l}52.5 \\
54.5\end{array}$ & $\begin{array}{l}51.2-53.8 \\
53.7-56.3\end{array}$ & $\begin{array}{l}-0.70 \\
-0.10\end{array}$ & $\begin{array}{l}-2.51-1.12 \\
-2.40-1.26\end{array}$ & $\begin{array}{l}1.30 \\
0.40\end{array}$ & $\begin{array}{l}-0.74-3.34 \\
-1.53-2.36\end{array}$ & $\begin{array}{l}-2.00 \\
-0.50\end{array}$ & $\begin{array}{r}0.02-3.98 \\
-0.90-2.87\end{array}$ \\
\hline \multicolumn{13}{|l|}{ Palm-digit } \\
\hline $\begin{array}{l}\text { Right side } \\
\text { Left side }\end{array}$ & $\begin{array}{l}55.1 \\
59.9\end{array}$ & $\begin{array}{l}53.3-56.8 \\
57.7-62.1\end{array}$ & $\begin{array}{l}50.9 \\
55.6\end{array}$ & $\begin{array}{l}49.4-52.4 \\
53.8-57.3\end{array}$ & $\begin{array}{l}54.2 \\
57.9\end{array}$ & $\begin{array}{l}52.5-55.9 \\
55.8-60.0\end{array}$ & $\begin{array}{l}0.90 \\
2.00\end{array}$ & $\begin{array}{l}-1.58-3.23 \\
-0.97-4.97\end{array}$ & $\begin{array}{l}4.20 \\
4.30\end{array}$ & $\begin{array}{l}1.91-6.46 \\
1.57-7.10\end{array}$ & $\begin{array}{l}-3.30 \\
-2.30\end{array}$ & $\begin{array}{r}1.07-5.63 \\
-0.36-5.03\end{array}$ \\
\hline \multicolumn{13}{|l|}{ Wrist-palm } \\
\hline $\begin{array}{l}\text { Right side } \\
\text { Left side }\end{array}$ & $\begin{array}{l}49.3 \\
50.1\end{array}$ & $\begin{array}{l}47.2-51.4 \\
47.7-52.5\end{array}$ & $\begin{array}{l}51.0 \\
53.4\end{array}$ & $\begin{array}{l}48.3-53.6 \\
50.6-56.3\end{array}$ & $\begin{array}{l}52.4 \\
53.5\end{array}$ & $\begin{array}{l}50.0-54.8 \\
51.1-55.9\end{array}$ & $\begin{array}{l}-3.10 \\
-3.40\end{array}$ & $\begin{array}{l}-6.21-0.16 \\
-6.76--0.03\end{array}$ & $\begin{array}{l}-1.70 \\
-3.30\end{array}$ & $\begin{array}{l}-4.96-1.71 \\
-7.02-0.36\end{array}$ & $\begin{array}{l}-1.40 \\
-0.10\end{array}$ & $\begin{array}{l}-2.11-4.91 \\
-3.58-3.71\end{array}$ \\
\hline \multicolumn{13}{|l|}{ Amplitude } \\
\hline \multicolumn{13}{|l|}{ Wrist-digit } \\
\hline $\begin{array}{l}\text { Right side } \\
\text { Left side }\end{array}$ & $\begin{array}{l}14.8 \\
14.0\end{array}$ & $\begin{array}{l}13.2-16.3 \\
12.4-15.7\end{array}$ & $\begin{array}{l}16.2 \\
15.6\end{array}$ & $\begin{array}{l}14.8-17.6 \\
14.0-17.1\end{array}$ & $\begin{array}{l}14.4 \\
15.5\end{array}$ & $\begin{array}{l}13.1-15.6 \\
14.2-16.8\end{array}$ & $\begin{array}{r}0.40 \\
-1.50\end{array}$ & $\begin{array}{l}-1.55-2.35 \\
-3.48-0.64\end{array}$ & $\begin{array}{l}-1.40 \\
-1.60\end{array}$ & $\begin{array}{l}-3.52-0.64 \\
-3.73-0.77\end{array}$ & $\begin{array}{l}1.80 \\
0.10\end{array}$ & $\begin{array}{l}-3.67--0.02 \\
-2.08-1.96\end{array}$ \\
\hline \multicolumn{13}{|l|}{ Palm-digit } \\
\hline $\begin{array}{l}\text { Right side } \\
\text { Left side }\end{array}$ & $\begin{array}{l}11.9 \\
12.2\end{array}$ & $\begin{array}{l}105-13.1 \\
10.9-13.5\end{array}$ & $\begin{array}{l}11.3 \\
13.0\end{array}$ & $\begin{array}{l}10.0-12.7 \\
11.6-14.3\end{array}$ & $\begin{array}{l}11.5 \\
13.6\end{array}$ & $\begin{array}{l}10.4-12.7 \\
12.2-14.9\end{array}$ & $\begin{array}{r}0.40 \\
-1.40\end{array}$ & $\begin{array}{l}-1.35-2.09 \\
-3.14-0.45\end{array}$ & $\begin{array}{r}0.60 \\
-0.80\end{array}$ & $\begin{array}{l}-1.35-2.41 \\
-2.56-1.05\end{array}$ & $\begin{array}{l}-0.20 \\
-0.60\end{array}$ & $\begin{array}{l}-1.60-1.92 \\
-1.26-2.45\end{array}$ \\
\hline
\end{tabular}


ity of the sensory nerve for the palm-to-digit segment showed a difference of $4.2 \mathrm{~m} \cdot \mathrm{s}^{-1}$ (95\% CI 1.91 6.46) for the right hand and $4.3 \mathrm{~m} \cdot \mathrm{s}^{-1}(95 \% \mathrm{CI}$ $1.57-7.10$ ) for the left hand between the two groups. For the plater and assembler categories the distal latencies over the carpal tunnel segment of the arm were prolonged compared with the latencies for the office worker group. The corresponding (wrist-palm segment) sensory nerve conduction velocities were also reduced in comparison with the velocities for the office workers (table 3 ).

The conduction velocities of the sensory nerve were slower for the right hand than for the left. When the conduction velocities were fractionated for the wrist-digit segment, the difference between the right and left hands was $-2.6 \mathrm{~m} \cdot \mathrm{s}^{-1}(95 \% \mathrm{CI}-3.45$ to $-1.76)$ for the platers, $-3.5 \mathrm{~m} \cdot \mathrm{s}^{-1}(95 \% \mathrm{CI}-4.76$ to $-2.23)$ for the assemblers, and $-2.5 \mathrm{~m} \cdot \mathrm{s}^{-1}(95 \% \mathrm{CI}$ -3.55 to -1.43 ) for the office workers.

The highest prevalences for impaired nerve conduction were found for the platers. The prevalence for a prolonged distal latency was higher for the vibration-exposed categories than for the office worker group (table 4). A long latency time was more prevalent among the platers than among the assemblers. In the plater group a long latency time was more prevalent for the left hand than for the right. For the assemblers a slightly higher prevalence of prolonged distal latency time was found for the right hand than for the left. The prevalence of impaired nerve con-

Table 4. Prevalence rates (\%) of nerve conduction impairment in relation to the $95 \%$ confidence interval ( $95 \% \mathrm{Cl}$ ) in the reference group, among the vibration-exposed subjects and the referents. The rate ratio is given with its $95 \% \mathrm{Cl}$.

\begin{tabular}{|c|c|c|c|c|c|c|c|c|}
\hline \multirow[b]{3}{*}{ Median nerve } & \multicolumn{6}{|c|}{ Study groups } & \multirow[b]{3}{*}{ Rate ratio } & \multirow[b]{3}{*}{$95 \% \mathrm{Cl}$} \\
\hline & \multirow[b]{2}{*}{$\begin{array}{c}\text { All } \\
\text { vibration } \\
\text { exposed } \\
(N=134)\end{array}$} & \multirow[b]{2}{*}{$\begin{array}{c}\text { Platers + } \\
\text { assem- } \\
\text { blers } \\
(N=114)\end{array}$} & \multirow[b]{2}{*}{$\begin{array}{l}\text { Platers } \\
(N=56)\end{array}$} & \multirow[b]{2}{*}{$\begin{array}{l}\text { Assem- } \\
\text { blers } \\
(N=58)\end{array}$} & \multicolumn{2}{|c|}{ Office workers } & & \\
\hline & & & & & $\begin{array}{c}\text { All } \\
(N=61)\end{array}$ & $\begin{array}{l}\text { Non- } \\
\text { vibration- } \\
\text { exposed } \\
(\mathrm{N}=45)\end{array}$ & & \\
\hline \multicolumn{9}{|l|}{ Motor } \\
\hline \multicolumn{9}{|l|}{ Distal latency } \\
\hline Left arm & $\begin{array}{c}\dot{ } \\
\dot{4} \\
\dot{5} \\
\dot{.} \\
\dot{.}\end{array}$ & $\begin{array}{c}44 \\
\cdot \\
\cdot \\
\cdot \\
\cdot \\
. \\
41 \\
\cdot\end{array}$ & $\begin{array}{c}50 \\
\cdot \\
\cdot \\
50 \\
\cdot \\
\dot{-} \\
43\end{array}$ & $\begin{array}{c}\cdot \\
38 \\
\dot{ } \\
38 \\
\cdot\end{array}$ & $\begin{array}{c}25 \\
25 \\
25 \\
\cdot \\
\cdot \\
\cdot \\
25 \\
25\end{array}$ & $\begin{array}{c}\cdot \\
\cdot \\
- \\
27 \\
27 \\
27 \\
\cdot \\
-\end{array}$ & $\begin{array}{l}1.78 \\
2.03 \\
1.54 \\
1.51 \\
1.86 \\
1.42 \\
1.68 \\
1.74\end{array}$ & $\begin{array}{l}1.10-2.90 \\
1.22-3.39 \\
0.89-2.67 \\
0.89-2.56 \\
1.08-3.25 \\
0.79-2.56 \\
1.03-2.74 \\
1.02-2.97\end{array}$ \\
\hline Right arm & $\begin{array}{c}38 \\
\dot{5} \\
\dot{.} \\
.\end{array}$ & $\begin{array}{c}\cdot \\
\dot{.} \\
\dot{*} \\
\dot{ } \\
\dot{ }\end{array}$ & $\begin{array}{c}: \\
\dot{4} \\
\dot{*} \\
5 \\
5\end{array}$ & $\begin{array}{c}40 \\
\dot{5} \\
\dot{\cdot} \\
\dot{4} \\
40\end{array}$ & $\begin{array}{c}25 \\
\cdots \\
\cdot \\
33 \\
33 \\
33\end{array}$ & $\begin{array}{c}27 \\
27 \\
27 \\
- \\
. \\
.\end{array}$ & $\begin{array}{l}1.61 \\
1.43 \\
1.61 \\
1.49 \\
1.45 \\
1.69 \\
1.21\end{array}$ & $\begin{array}{l}0.94-2.77 \\
0.84-2.43 \\
0.91-2.85 \\
0.83-2.65 \\
0.96-2.17 \\
1.10-2.59 \\
0.75-1.95\end{array}$ \\
\hline Sensory & & . & & & & & & \\
\hline \multicolumn{9}{|c|}{ Conduction velocity } \\
\hline Left side & $\begin{array}{c}44 \\
: \\
:\end{array}$ & $\dot{\cdot} \cdot \dot{\cdot}$ & $\begin{array}{c}\dot{55} \\
\dot{6} \\
61\end{array}$ & $\dot{4} \cdot$ & $\begin{array}{c}. \\
. \\
46 \\
46\end{array}$ & $\begin{array}{c}33 \\
33 \\
33 \\
\cdot \\
\cdot\end{array}$ & $\begin{array}{l}1.32 \\
1.66 \\
1.19 \\
1.13 \\
1.32\end{array}$ & $\begin{array}{l}0.84-2.08 \\
1.03-2.67 \\
0.71-2.00 \\
0.82-1.56 \\
0.94-1.87\end{array}$ \\
\hline Right side & $\begin{array}{c}52 \\
. \\
. \\
. \\
.\end{array}$ & $\begin{array}{l}\cdot \\
\dot{.} \\
\dot{4} \\
\dot{5}\end{array}$ & $\begin{array}{c}\cdot \\
61 \\
\dot{5} \\
54 \\
\cdot\end{array}$ & $\begin{array}{c}43 \\
: \\
43 \\
\dot{5} \\
43\end{array}$ & $\begin{array}{c}46 \\
\cdot \\
\cdot \\
\cdot \\
34 \\
34 \\
34\end{array}$ & $\begin{array}{c}\dot{4} \\
44 \\
44 \\
\dot{.} \\
.\end{array}$ & $\begin{array}{l}0.94 \\
1.16 \\
1.37 \\
0.97 \\
1.40 \\
1.56 \\
1.25\end{array}$ & $\begin{array}{l}0.63-1.40 \\
0.80-1.67 \\
0.93-2.02 \\
0.62-1.51 \\
0.94-2.08 \\
1.02-2.38 \\
0.79-1.97\end{array}$ \\
\hline \multicolumn{9}{|l|}{ Amplitude } \\
\hline \multicolumn{9}{|l|}{ Wrist-palm } \\
\hline Left side & $\begin{array}{c}47 \\
\cdot \\
\cdot \\
\cdot\end{array}$ & $\begin{array}{c}\cdot \\
\dot{5} \\
35 \\
\cdot\end{array}$ & $\begin{array}{c}54 \\
: \\
\dot{4} \\
45\end{array}$ & $\dot{4}$ & $\begin{array}{c}\dot{.} \\
34 \\
34\end{array}$ & $\begin{array}{l}33 \\
33 \\
33 \\
. \\
.\end{array}$ & $\begin{array}{l}1.41 \\
1.61 \\
1.29 \\
1.02 \\
1.30\end{array}$ & $\begin{array}{l}0.90-2.21 \\
1.00-2.60 \\
0.78-2.15 \\
0.67-1.56 \\
0.83-2.04\end{array}$ \\
\hline Right side & 37 & $\dot{.}$. & $\begin{array}{c}\cdot \\
- \\
45 \\
\cdot\end{array}$ & $\begin{array}{c}26 \\
\cdot \\
\dot{2}\end{array}$ & $\begin{array}{c}34 \\
\cdot \\
\cdot\end{array}$ & $\begin{array}{l}. \\
33 \\
33 \\
33\end{array}$ & $\begin{array}{l}0.75 \\
1.10 \\
1.34 \\
0.78\end{array}$ & $\begin{array}{l}0.43-1.31 \\
0.69-1.75 \\
0.81-2.22 \\
0.43-1.41\end{array}$ \\
\hline
\end{tabular}


Table 5. Log-likelihood, constant exposure, and odds ratios from unconditional multiple logistic regression models of prolonged distal latency time over the carpal tunnel segment of the arms. $(R R=$ rate ratio)

\begin{tabular}{|c|c|c|c|c|c|c|c|c|c|c|}
\hline \multirow{3}{*}{ Variable } & \multicolumn{2}{|c|}{ Model 1} & \multicolumn{2}{|c|}{ Model 2} & \multicolumn{2}{|c|}{ Model 3} & \multicolumn{2}{|c|}{ Model 4} & \multicolumn{2}{|c|}{ Model 5} \\
\hline & \multicolumn{2}{|c|}{$\mathrm{RR}^{\mathrm{a}}$} & \multicolumn{2}{|c|}{$\mathrm{RR}^{\mathrm{a}}$} & \multicolumn{2}{|c|}{$\mathrm{RR}^{\mathrm{a}}$} & \multicolumn{2}{|c|}{$\mathrm{RR}^{\mathrm{a}}$} & \multicolumn{2}{|c|}{$\mathrm{RA}^{\mathrm{a}}$} \\
\hline & Right hand & Left hand & Right hand & Left hand & Right hand & Left hand & Right hand & Left hand & Right hand & Left hand \\
\hline Log-likelihood & -116.10 & -117.68 & -106.69 & -107.42 & -91.46 & -93.21 & -90.38 & -92.60 & -104.85 & -104.41 \\
\hline Constant exposure $(\alpha)$ & $\begin{array}{c}0.515 \\
(0.186- \\
1.425)\end{array}$ & $\begin{array}{c}0.445 \\
(0.162- \\
1.222)\end{array}$ & $\begin{array}{c}0.467 \\
(0.154- \\
1.413)\end{array}$ & $\begin{array}{c}0.317 \\
(0.105- \\
0.964)\end{array}$ & $\begin{array}{c}0.587 \\
(0.159- \\
2.175)\end{array}$ & $\begin{array}{c}0.554 \\
(0.154- \\
1.998)\end{array}$ & $\begin{array}{c}1.011 \\
(0.126- \\
8.1117)\end{array}$ & $\begin{array}{c}0.412 \\
(0.050- \\
3.381)\end{array}$ & $\begin{array}{c}0.171 \\
(0.033- \\
0.895)\end{array}$ & $\begin{array}{c}0.104 \\
(0.019- \\
0.570)\end{array}$ \\
\hline Age (number of years) & $\begin{array}{c}1.002 \\
(0.972- \\
1.033)\end{array}$ & $\begin{array}{c}1.009 \\
(0.979- \\
1.039)\end{array}$ & $\begin{array}{c}1.007 \\
(0.975- \\
1.040)\end{array}$ & $\begin{array}{c}1.020 \\
(0.988- \\
1.052)\end{array}$ & $\begin{array}{c}0.986 \\
(0.947- \\
1.027)\end{array}$ & $\begin{array}{c}0.992 \\
(0.954- \\
1.032)\end{array}$ & $\begin{array}{c}0.973 \\
(0.922- \\
1.028)\end{array}$ & $\begin{array}{c}0.998 \\
(0.946- \\
1.053)\end{array}$ & $\begin{array}{c}1.022 \\
(0.983- \\
1.063)\end{array}$ & $\begin{array}{c}1.034 \\
(0.994- \\
1.076)\end{array}$ \\
\hline \multicolumn{11}{|l|}{$\begin{array}{l}\text { Nicotine (nonconsumers } \\
\text { or ex-consumers versus } \\
\text { active smokers or }\end{array}$} \\
\hline snuff users) & & & $\begin{array}{c}1.015 \\
(0.536- \\
1.924)\end{array}$ & $\begin{array}{l}1.176 \\
(0.622- \\
2.223)\end{array}$ & $\begin{array}{c}0.912 \\
(0.448- \\
1.858)\end{array}$ & $\begin{array}{c}0.916 \\
(0.454- \\
1.848)\end{array}$ & $\begin{array}{c}0.979 \\
(0.475- \\
2.019)\end{array}$ & $\begin{array}{c}0.933 \\
(0.458- \\
1.899)\end{array}$ & $\begin{array}{c}0.913 \\
(0.471- \\
1.771)\end{array}$ & $\begin{array}{c}1.008 \\
(0.519- \\
1.958)\end{array}$ \\
\hline \multicolumn{11}{|l|}{$\begin{array}{l}\text { Vibration number of } \\
\text { years with vibration }\end{array}$} \\
\hline exposure & & & & & $\begin{array}{c}1.068 \\
(1.016- \\
1.123)\end{array}$ & $\begin{array}{c}1.079 \\
(1.026- \\
1.135)\end{array}$ & $\begin{array}{c}1.121 \\
(1.024- \\
1.228)\end{array}$ & $\begin{array}{c}1.093 \\
(0.999- \\
1.195)\end{array}$ & & \\
\hline Assembling & & & & & & & $\begin{array}{l}0.786 \\
(0.223- \\
2.767)\end{array}$ & $\begin{array}{l}1.422 \\
(0.400- \\
5.048)\end{array}$ & $\begin{array}{l}2.369 \\
(0.863- \\
6.501)\end{array}$ & $\begin{array}{l}2.573 \\
(0.920- \\
7.193)\end{array}$ \\
\hline Plating & & & & & & & $\begin{array}{c}0.369 \\
(0.075- \\
1.803)\end{array}$ & $\begin{array}{l}0.821 \\
(0.172- \\
3.917)\end{array}$ & $\begin{array}{l}2.108 \\
(0.879- \\
5.055)\end{array}$ & $\begin{array}{c}2.839 \\
(1.177- \\
6.847)\end{array}$ \\
\hline
\end{tabular}

a $95 \%$ confidence interval in parentheses.

duction over the carpal tunnel and a reduced amplitude were more prevalent among the platers and the assemblers than among the referents for the right hand but not for the left hand for the assemblers.

Rate ratios (RR) of 1.4-2.0 were found for impaired nerve conduction over the carpal tunnel segment for the distal latency and $0.9-1.7$ for the nerve conduction velocity (table 4 ). The rates were generally higher for the left-hand side than for the righthand side. For the arm and for the palm-to-finger segments the risks of impaired nerve conduction were not increased. The highest rate ratios were found for the distal latency. An increased risk for a prolonged distal latency, reduced nerve conduction velocity, and decreased amplitude was found for the platers and the assemblers when contrasted to the office workers (table 4). An increased risk was also found when the vibration-exposed workers, irrespective of job title, were contrasted to nonvibration-exposed office workers. The corresponding magnitudes of the risk were higher when the contrast was based on job title than when the contrast was based only on exposure to vibration. The risks were generally higher for the left-hand side than for the right-hand side. The rate ratios were generally higher for the platers than for the assemblers.

In a logistic regression model controlling for age, nicotine use, and years of vibration exposure, it was found that the duration of vibration exposure was a predictor of prolonged distal latency. An increased risk (RR 1.12, 95\% CI 1.02-1.23 for the right hand; RR $1.09,95 \%$ CI $1.00-1.20$ for the left hand) for prolonged distal latency remained when the model was expanded to control for assembling and plating (table 5).

\section{Discussion}

\section{Exposure}

The study groups had a vibration exposure distribution of low to moderate. The vibration exposure from plating work was moderately high $\left(4.6 \mathrm{~m} \cdot \mathrm{s}^{-2}\right)$ when compared with the recommended $4.0 \mathrm{~m} \cdot \mathrm{s}^{-2}$ threshold level suggested by the American Conference of Governmental Industrial Hygienists (11). The platers' exposure values were lower than the 4-h equivalent vibration exposure reported for stone drillers and stone cutters $\left(22.7 \mathrm{~m} \cdot \mathrm{s}^{-2}\right)(12)$ but higher than the level found in riveting $\left(2.8 \mathrm{~m} \cdot \mathrm{s}^{-2}\right)(13)$. The vibration exposure in the plater group came exclusively from power tools. High-impulse vibration exposure originating from the mechanical components of plating work shown by Starck et al (14) was negligible in our study when compared with the contribution from the power tools. In the truck assembly group the mean 4-h frequency-weighted acceleration was very low $\left(1.0 \mathrm{~m} \cdot \mathrm{s}^{-2}\right)$. The vibration exposure of this group was of the same magnitude as that of the "manual task group" used as a reference group by Burdorf et al (13) and lower than the exposure of Japanese sewing machine operators (15). Most of the vibration exposure among the platers and assemblers was of low to medium frequency; thus the loss of information from frequency-weighting should be of minor significance. 
The durations of vibration exposure were comparable for the left and right hands, albeit with a small predominance for the right hand. This finding indicates the frequently used double-handed grip of the power tools.

The hand-transmitted vibration exposure was confounded by ergonomic work factors. The jobs involving use of vibrating tools also involved a considerable use of the upper limbs and therefore also ergonomic stress due to executed force, repetitiveness, posture, contact stress, and cold temperature (16). A high level of forced grip is one of several ergonomic factors (together with extension and flexion postures and repetitiveness) associated with an increased risk of carpal tunnel syndrome (17). In this investigation we only measured one of these factors, the fraction of the worktime when the forced grip was used. The outcome showed that the duration of forced grip was twice as long for the assembler group than for the plater group. This result is in agreement with the more pronounced manual aspects of assembly work compared with plating. There was a predominance of a forced grip for the right hand among the assemblers which was not found for the platers. This outcome can be interpreted as further evidence of the manual character of assembly work.

There is a bilateral interaction between exposure from ergonomic work factors and vibration. Ergonomic work factors can adversely affect vibration transmission and exposure. Vibration can influence the average grip force (16), while, at the same time, forceful gripping can result in increased vibration transfer to the hands due to improved coupling (18).

\section{Effect measures}

Special interest has been focused on neurophysiological findings in the wrist segment of the arm, as the susceptibility of the axon is increased where the nerves and tendons pass through the narrow carpal tunnel. Neuropathy caused by compression of the median nerve at the carpal tunnel accompanied by characteristic symptoms make up the carpal tunnel syndrome (19). The severity of the syndrome ranges from mild symptoms with only nocturnal paresthesia and normal electroneurophysiological findings to severe symptoms and complete nerve conduction block (20).

We found the highest risks of impaired nerve conduction for the carpal tunnel in comparison with the other segments of the arm. There was no increment in the risk for the palm-finger segment or for the armwrist segment. This localized effect on the median nerve at the carpal tunnel segment is consistent with the findings of earlier investigations $(21,22)$, although there are also conflicting results (6).

\section{Exposure effect}

In spite of different jobs, tasks, and exposures no major differences were found between the mean nerve conduction measures for the assemblers and platers, except for the palm-digit parameter. The reduced peripheral conduction velocity for the palmdigit segment among the assemblers may have been due to a difference in the measurement procedure. The conduction velocity was recorded from the second digit for the assemblers but from the third digit for the other groups.

Investigators of nerve conduction have often studied the effect from exposure in one single type of job $(23,24)$, or in case series (25), and only to a less extent have the results been compared with the results of reference groups. Among the publications in which reference groups have been used $(6,22)$, there have been no detailed descriptions of the work tasks of the reference groups, and this situation hampers the possibility of comparing the results.

The risk of impaired nerve conduction was higher for the platers than for the assemblers when these groups were contrasted to the office workers. The strength of the association between exposure and response expressed as the magnitude of the relative risk was only moderately increased in our study, the rate ratios not exceeding 2.0 with a corresponding agestandardized odds ratio of 3.2 (95\% CI 1.4-7.0). The differences in the rate ratios between the platers and the assemblers were of the magnitude of 0.5 , when compared with the fivefold wider confidence intervals. Our magnitude of risk is comparable with the 2.3 odds ratio ( $95 \% \mathrm{CI} 1.4-3.7$ ) recalculated by Hagberg et al (17) from the results of a cross-sectional study in which assembly workers were contrasted to administrative personnel (26).

When the contrast was based on vibration exposure alone, a reduced rate ratio was found in comparison with the corresponding values for the job titles platers and assemblers. This finding can be interpreted as dilution due to former vibration exposure in the office worker group. The highest rate ratios were found for the platers when contrasted to the office workers, and this finding is compatible with the distribution of the highest vibration exposure to this group. The outcome showed that the platers' exposure to work with vibrating tools was twice the duration of that of the assemblers, and it was of a higher intensity, but the corresponding risk was only slightly increased and not consistently so. The risks of impaired nerve conduction were generally higher for the left hand than for the right despite the slightly higher vibration exposure and the higher duration of forced grips for the right hand. The difference in vibration exposure between the platers and assemblers was even larger when the exposure was unweighted rather than frequency-weighted. In our study there was no evidence of a relationship between cumulative vibration exposure and the severity of nerve conduction impairment.

The rate ratios were higher when the contrast was based on job title than when the risk was based only on exposure to vibrating power tools. This result in- 
dicates that nonvibration exposure factors associated with work, for example, the biomechanical aspects, were also important. Among the important discriminants of physical work load are, for example, repetitive movements, forceful gripping, and static posture (17). Several investigators $(23,27)$ have associated compression of the median nerve at the carpal tunnel with both exposure to vibration and manual work. The variation in manual work load, due to ergonomic factors, in different occupations is associated with an increased prevalence of carpal tunnel syndrome (26). High prevalences of carpal-tunnel syndrome have been observed by Silverstein et al (28) in industrial occupations where exposure to high-force and repetitive hand wrist movements are frequent. In their study the relative risk of carpal-tunnel syndrome was 15 for occupations with high force and repetitive hand movements. Estimated from a logistic model, controlling for high force and high repetition, the risk was 1.9 (not significant) for vibration exposure.

The sensory nerve conduction velocities were lower in the right hand than the left in all of our groups. But when the risk estimates (rate ratio) for impaired nerve conduction are considered, they were increased for the left hand when it was compared with the right. Our reported increment in risk for the left hand cannot be explained by vibration exposure alone. A lateralization of increased risk measures to the nondominant hand has also been shown for other effect measures (arthritis) (29). In office work, as well as in plating and assembling, the highest ergonomic work load (occupational and nonoccupational) is predominantly directed towards the dominant hand, most often the right hand. The relative impact of some other specific exposure (ie, vibration) may thus be larger for the nondominant hand, due to a lower total work load, compared with the dominant hand.

In a multiple logistic regression model controlling for age, use of nicotine, and job (inclusion of plating or assembling), each working year, including work with vibrating power tools, increases the odds ratio for a prolonged distal latency by $12 \%$ for the right hand and $9 \%$ for the left. This result points to both occupational work characteristics and vibration confounded by repetitive and forceful gripping as important risk factors for impaired nerve conduction over the carpal tunnel segment. The magnitudes of the attributable proportions from vibration exposure and physical work load are still the subject of debate $(17,30)$.

\section{Study design considerations}

Possible bias in study base selection. The cross-sectional study had a census design for the plater and assembler categories and random admission for the office workers. The missing frequency (absent, studying, long-time sickness) in the base population was 20 and $39 \%$ for the platers and assemblers, re- spectively. Due to restricted access to neurophysiological investigation facilities only the first 60 (61, 60 , and 58) consecutive subjects in each group were given a neurophysiological examination. The platers and assemblers absent during the study period were thus omitted. The subjects with increased absenteeism due to health problems may have been excluded, and this possibility could have led to an underestimation of the true risk. All of the office workers were examined. Among the office workers most of the work was worldwide maintenance and selling. Traveling attracts young and healthy subjects. Therefore the mean age of the office workers accessible to the study was high, and there may have been a possible selection of those office workers with less vigor. The net effect of this possible selection bias could be an underestimation of the true risk.

The effect of selection bias (healthy worker effect) in the plater group was regarded as low due to a very low (4\%) yearly turnover compared with that of the assembly group, for which the yearly turnover was high (20\%). This high turnover in the assembly group was interpreted not as being primarily linked to health or comfort problems but instead to a normal short work career for young unskilled workers in monotonous assembly work.

Possible misclassification of exposure. In this investigation the exposure categories were based on belonging to a job with known exposure to vibration and ergonomic work load. Detailed analyses of exposure to vibration revealed that job title was a crude measure of exposure to vibration. In the reference group $25 \%$ of the office workers had had substantial exposure to vibration in their previous jobs. Among the platers a small fraction worked with tasks in which there was no current vibration exposure. In these analyses only occupational vibration exposure was controlled for. There could have been substantial exposure from leisure-time activities such as driving snowmobiles or other vehicles with vibrating handlebars or using powered handtools. The assumption of an even distribution of such leisure-time exposure in the exposure and reference groups can be questioned on the grounds of the different age distributions.

The outcome shows a high concordance between the reported time of exposure to vibrating tools during the day of the investigation and the corresponding objectively measured exposure time. This finding can be interpreted as indicating the subjects' knowledge of the content of their work. The reliability of reported exposure in the past cannot be validated. According to the plating company no major changes had occurred in exposure during the last 10 years. Recall bias from past exposure is more apt to show among those with a long occupational history, which could be associated with age. No indi- 
cations of uncertainty in the collected information on years of work was addressed.

Ergonomic exposure was asked for or analyzed for former occupations or leisure-time activities. The influence of sports, former work, and leisure time could thus not be controlled for.

Possible missclassification of cases. The 95\% upper limit of the mean in the nonvibration-exposed reference group was used as the case criterion for impaired nerve conduction. The value used for a prolonged distal latency of the median motor nerve ( $>3.74$ and $>3.73 \mathrm{~ms}$ ) was shorter than the criterion used for medical purposes (>4.2 $\mathrm{ms}$ ). The case criterion for a reduced conduction velocity of the median sensory nerve was fast $\left(<50.0\right.$ and $\left.50.1 \mathrm{~m} \cdot \mathrm{s}^{-1}\right)$ compared with the medical criterion $\left(<39 \mathrm{~m} \cdot \mathrm{s}^{-1}\right)$. The prevalences of impaired nerve conduction were thus not compatible with the prevalences found when the medical diagnostic criteria for neuropathy in the carpal tunnel syndrome are used. Choosing these criteria means that a high point prevalence for neurological impairment is to be expected by definition. High point prevalences for prolonged distal latencies and nerve conduction velocities were also found for the platers, the assemblers, and the office workers.

The case definitions were not adjusted for the differences in age and anthropometry between the reference group and the exposure groups. The observed correlations between conduction measures and age, height, and weight were relatively low and would explain only a small fraction of the variance. The negative correlation between the effect parameters and age might have resulted in an underestimation of the risk.

Polyneuropathy and other diseases have been controlled for in only a few of the earlier studies on nerve conduction $(22,31,32)$. The nerve conduction findings do not differentiate between diffuse general distal neuropathy due to disease and local entrapment neuropathies with other possible origins. A small fraction of our subjects can be expected to have had untreated diseases or alcohol overconsumption accompanied by polyneuropathy. This factor might be unevenly distributed among the office workers, as they were older and, as such, more susceptible to disease. The recurrent health surveys performed by the companies' occupational health services diminished the magnitude of this possible risk however.

Possible confounding. Individual characteristics associated with increased susceptibility may confound the effect of exposure. The confounders age and use of nicotine were controlled for because of their biological and theoretical importance. The exposure characteristics correlated with age are several lifestyle characteristics, including activity in sports, leisure-time use of vehicles with vibrating handlebars, and recurrent episodes of excessive alcohol consumption.

Possible inadequate choice of effect measure. According to the hypothesis of trauma leading to edema, fibrin, and damage (20), there are reversible short-term effects in the early stage of the carpal tunnel syndrome and remaining damage in the advanced stage of the syndrome. Sensitivity to the effects of short-term edema compared with the long-term effects has not been specified for the measurement methods used. In our study we measured the maximal conduction velocity, which mirrors the function in the thickly myelinated fibers. It has been claimed (33) that it is the thin unmyelinated fibers that are primarily damaged in the early stages of carpal tunnel syndrome.

Possible uncertainty in the time-effect relationship. The cross-sectional study design does not distinguish the onset of abnormal nerve function, and it does not permit an analysis of the time characteristics for the influence of work with vibrating tools on nerve function. It is not known whether the results are caused by exposure that occurred a long time ago or if they are an acute reversible effect.

\section{Concluding remarks}

The sensory nerve conduction velocities were reduced in the right hand in comparison with the left in all of the groups investigated. However the risk measurements (rate ratio) for impaired nerve conduction were increased for the left hand when compared with the right. The increased risk for objectively measured effects on the nerves in the platers and assemblers, when contrasted to office workers, indicate that vibration and the biomechanical aspects of work are important for nerve conduction impairment in the carpal tunnel. The contributions from vibration and ergonomic factors were inseparable in this study. However the outcome from the assembly work, where a low intensity of vibration exposure, as measured by ISO 5349 (7) and short employment times still gave clear effects, points towards the importance of the manual aspects of the work or to an inadequacy in the ISO 5349 standard in measuring those aspects of vibration relevant for adverse health effects on the nerves.

Preventive measures for reducing neuropathy and, specifically, the carpal tunnel syndrome should thus focus not only on vibration exposure, but also on the different ergonomic aspects of the work.

\section{Acknowledgments}

Financial support from the Swedish Work Environment Fund is gratefully acknowledged. 
Gratitude is expressed to Ms A Fägerstrand for carrying out the neurophysiological measurements

\section{References}

1. Taylor W. Biological effects of the hand-arm vibration syndrome: historical perspective and current research. J Acoust Soc Am 1988;83(2):415-22.

2. Brammer AJ, Taylor W, Lundborg G. Sensorineural stages of the hand-arm vibration syndrome. Scand J Work Environ Health 1987;13(4):279-83.

3. Ekenvall L, Nilsson BY, Falconer C. Sensory perception in the hands of dentists. Scand J Work Environ Health 1990;16(5):334 9 .

4. Bovenzi M, Zadini A. Quantitative estimation of aesthesiometric thresholds for assessing impaired tactile sensation in workers exposed to vibration. Int Arch Occup Environ Health 1989;61(7):431-5.

5. Brammer AJ, Piercy JE, Auger PL, Nohara S. Tactile perception in hands occupationally exposed to vibration. J Hand Surg 1987;12A:870-5.

6. Brammer AJ, Pyykkö I. Vibration-induced neuropathy: detection by nerve conduction measurements. Scand J Work Environ Health 1987;13(4):317-22.

7. International Organization for Standardization (ISO). Vibration and shock - guidelines for the measurement and the assessment of human exposure to hand-transmitted vibration. Geneva: ISO, 1986. ISO 5349.

8. Hernberg S. Introduction to occupational epidemiology. Chelsea: Lewis Publishers, 1992.

9. Checkoway H, Pearce N, Crawford-Brown D. Research methods in occupational epidemiology. Oxford: Oxford University Press, 1989.

10. Kleinbaum DG, Kupper LL, Morgenstern H. Epidemiologic research principles and quantitative methods. New York: Van Nostrand Reinhold Company, 1982.

11. Taylor W, Pelmear PL. The hand-arm vibration syndrome: an update [editorial]. Br J Ind Med 1990;47(9): 577-9.

12. Bovenzi M, Franzinelli A, Strambi F. Prevalence of vibration-induced white finger and assessment of vibration exposure among travertine workers in Italy. Int Arch Occup Environ Health 1988;61(1-2):25-34.

13. Burdorf A, Monster A. Exposure to vibration and selfreported health complaints of riveters in the aircraft industry. Ann Occup Hyg 1991;35(3):287-98.

14. Starck J, Pekkarinen J, Pyykkö I. Physical characteristics of vibration in relation to vibration-induced white finger. Am Ind Hyg Assoc J 1990;51(4):179-84.

15. Mirbod SM, Inaba R, Iwata $H$. A study on the vibration-dose limit for Japanese workers exposed to handarm vibration. Ind Health 1992;30:1-22.

16. Radwin RG, Armstrong TJ, Van Bergeijk E. Hand-arm vibration and work-related disorders of the upper limb. In: Pelmear PL, Taylor W, Wasserman DE, editors. Hand-arm vibration. New York, NY: Van Nostrand Reinhold, 1992:122-52.
17. Hagberg M, Morgenstern H, Kelsh M. Impact of occupations and job tasks on the prevalence of carpal tunnel syndrome. Scand J Work Environ Health 1992; $18: 337-45$.

18. Burström L. Measurements of the impedance of the hand and arm. Int Arch Occup Environ Health 1990;62:431-9.

19. Gelberman RH, Rydevik BL, Pess GM, Szabo RM, Lundborg G. Carpal tunnel syndrome: a scientific basis for clinical care. Orthop Clin North Am 1988; 19(1):115-24.

20. Lundborg G. Nerve injury and repair. London: Churchill Livingstone, 1988.

21. Brismar T, Ekenvall L. Nerve conduction in the hands of vibration exposed workers. Electroencephalogr Clin Neurophysiol 1992;85:173-6.

22. Chatterjee D, Barwick D, Petrie A. Exploratory electromyography in the study of vibration-induced white finger in rock drillers. Br J Ind Med 1982;39:89-97.

23. Koskimies K, Färkkilä M, Pyykkö I, Jäntti V, Aatola $\mathrm{S}$, Starck $\mathbf{J}$, et al. Carpal tunnel syndrome in vibration disease. Br J Ind Med 1990;47(6):411-16.

24. Färkkilä M, Pyykkö I, Aatola S, Korhonen O. Forestry workers exposed to vibration: a neurological study. Br J Ind Med 1988;45:188—92.

25. Lukás $E$. Lesion of the peripheral nervous system due to vibration. Work Environ Health 1970;7(1):67-79.

26. Nathan PA, Meadows KD, Doyle LS. Occupation as a risk factor for impaired sensory conduction of the median nerve at the carpal tunnel. J Hand Surg 1988; 13B(2): $167-70$.

27. Wieslander G, Norbäck D, Göthe CJ, Juhlin L. Carpal tunnel syndrome (CTS) and exposure to vibration, repetitive wrist movements, and heavy manual work: a case-referent study. Br J Ind Med 1989;46(1):437.

28. Silverstein BA, Fine LJ, Armstrong TJ. Occupational factors and carpal tunnel syndrome. Am J Ind Med 1987; 11(3):345-58.

29. Stenlund B, Goldie I, Hagberg M, Hogstedt C. Shoulder tendinitis and its relation to heavy manual work and exposure to vibration. Scand J Work Environ Health 1993;19:43-9.

30. Hadler NM. Arm pain in the workplace; a small area analysis. J Occup Med 1992;34;2:113-9.

31. Juntunen J, Matikainen E, Seppäläinen A, Laine A. Peripheral neuropathy and vibration syndrome: a clinical and neurophysiological study of 103 patients. Int Arch Occup Environ Health 1983;52:17-24.

32. Alaranta H, Seppäläinen AM. Neuropathy and the automatic analysis of electromyographic signals from vibration exposed workers. Scand J Work Environ Health 1977;3:128-34.

33. Lundborg G, Dahlin LB, Hansson HA, Kanje M, Necking LE. Vibration exposure and peripheral nerve fiber damage. J Hand Surg 1990;15A(2):346-51.

Received for publication: 25 February 1993 